\title{
Effect of xylitol on salivary Streptococcus mutans: a systematic review and meta-analysis
}

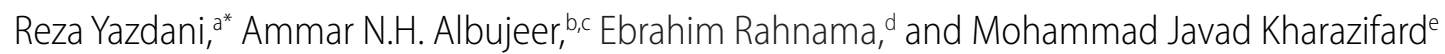

\author{
aDepartment of Community Oral Health, Faculty of Dentistry, Tehran University of Medical Sciences, International Campus, Tehran, Iran. \\ bPublic Health Unit, Nab'a Al-Hayat Foundation for Medical Sciences and Health Care, Najaf, Iraq. \\ 'School of Dentistry, Tehran University of Medical Sciences, Tehran, Iran. \\ dPrivate Dentist, Tehran, Iran \\ eDepartment of Community Oral Health, Faculty of Dentistry, Tehran University of Medical Sciences, Tehran, Iran. \\ *Correspondence to Reza Yazdani (email: ryazdani@tums.ac.ir) \\ (Submitted: 18 December 2018 - Revised version received: 19 January 2019 - Accepted: 25 January 2019 - Published online: 26 April 2019)
}

\begin{abstract}
Objectives This study aimed to systematically review the available randomized clinical trials (RCTs) on the effect of xylitol on the number of Streptococcus mutans (S. mutans) colonies.

Methods An electronic search was carried out in Medline and Scopus databases for the RCTs published during 2002-2014. The inclusion criteria were evaluation of xylitol gums, having at least one control group and counting S. mutans colonies. The articles were divided into three groups based on the subjects'age group namely 0-6,6-18 and above 18 years old. To assess the quality of RCTs, the retrieved articles were independently reviewed by two reviewers in terms of randomization and to prevent the effect of blinding on the results. Review Manager (RevMan) software, heterogeneity test and $R$ coefficient as the quantitative scale of heterogeneity were used for statistical analysis. Results Primary search of the literature using keywords related to sugar alcohols were carried out. After applying the inclusion criteria, 46 articles were found in PubMed and 356 in Scopus. Heterogeneity was not found in the two age groups of $6-18$ and above 18 years old and the $P^{2}$ coefficient in these two groups was $0 \%$. This rate for the $0-6$ years old was $51 \%(P=0.15)$; which indicates moderate heterogeneity. The $P$-value was $0.25,0.34$ and 0.04 for the $6-18,0-6$ and above 18 years old, respectively. This value was only significant for the age group of above 18 years old. Data for all groups were analyzed irrespective of age, which revealed significant differences $(P=0.01)$. Conclusion The available literatures show xylitol as an alternative sweetener, could help to prevent dental caries by reducing the count of S. mutans in the saliva.

Keywords dental caries, artificial sweetener, adults, child
\end{abstract}

\section{Introduction}

Dental caries is a multifactorial disease occurring as the result of an imbalance between the mineral structure of the tooth and oral biofilm. Cariogenic bacteria produce acids by metabolizing fermentable carbohydrates. Acid causes demineralization by dissolving calcium and phosphate in the structure of enamel and dentin. ${ }^{1}$ Dental caries is a controllable disease. However, it is considered a public health dilemma and affects majority of children and adults. ${ }^{2,3}$

The main etiology of dental caries is the nutritional habits of people, and consumption of sugar (carbohydrates) is believed to be the main cause. At present, attention is directed toward decreasing the consumption of sugar by the implementation of preventive strategies. ${ }^{4,5}$

Researchers are attempting to find an alternative for the currently used sugars and have come up with non-fermentable sugar alcohols for the purpose of caries prevention. Several studies have assessed the efficacy of sugar alcohols, especially xylitol, for prevention of dental caries, and their favorable efficacy in this regard has been previously confirmed..$^{6-8}$ Some previous studies showed that daily consumption of xylitol chewing gums and products were associated with a reduction in prevalence of caries. ${ }^{9-12}$ However, some others did not report any significant effect related to the consumption of xylitol and refuted its cariostatic effects. Xylitol has been introduced as a safe alternative to fermentable sugars for adolescents and the youth and reported to be a non-carcinogenic and even an anti-carcinogenic agent by the American Food and Drug Administration and the European food safety organizations. ${ }^{7}$ It has been confirmed that xylitol inhibits the growth and proliferation of Streptococcus mutans, which is the main microorganism responsible for the occurrence of dental caries. ${ }^{13}$ Fontana et al., ${ }^{14}$ evaluated the available review articles and guidelines related to the use of sugar alcohols and stated that extensive use of xylitol and other polyol sugars for preventive or therapeutic purposes requires further assessments with special attention to their efficacy and dosage for use in high-risk communities and their synergy with other preventive modalities. Considering the controversial results of previous clinical and review studies, this study sought to assess the effect of xylitol on the number of $S$. mutans colonies by performing a systematic review.

\section{Materials and Methods}

This systematic review was designed and carried out according to the Cochrane's Handbook for Systematic Reviews of Interventions (version 5.1.0). ${ }^{15}$

An electronic search was carried out in PubMed and Scopus databases for English randomized clinical trials (RCTs) or quasi-RCTs comparing the efficacy of sugar alcohols with the placebo for prevention of caries. Studies published during 2002-2014 with available full texts were searched. Non-RCTs, historical studies, single group studies with before/after designs, interrupted time series analyses, observational and retrospective studies and controlled before/after prospective cohort trials were excluded. 
The Medline and Scopus were searched using keywords in $\mathrm{MeSH}$ format as well as free words including "sugar alcohols" $(\mathrm{MeSH})$ or "sweetening agent" or "sweetener" or "artificial sweetener" or "sugar substitute" and "dental caries" (MeSH). After searching the databases, to eliminate the duplicates and also for the purpose of easy citation, the articles were entered into EndNote X7 (Bld 7072) software.

Studies on all age groups were searched. Articles on a population with specific health conditions (oral or systemic) such as mental retardation were excluded. Active intervention groups were those using sugar alcohols in the form of chewing gums, and studies on sugar alcohols consumed in other forms such as pills, drops, lozenges and sugar-saturated wipes were excluded.

Considering the small number of articles on different types of sugar alcohols, only those including an active intervention group using xylitol and a minimum of one control group not receiving xylitol or receiving placebo or any other form of preventive treatment (such as sealants, fluoridated toothpastes or specific hygienic instructions) were included.

With regard to the outcomes, only studies with a methodology based on counting $S$. mutans colony forming units (CFUs) under in vitro conditions were included.

Based on the variability in dosage of xylitol used in interventional studies and different measurement time points, we tried our best to select studies assessing similar time points, and those reporting data at time points or dosages very different from others were excluded.

Considering the fact that dental caries is a multifactorial disease and the confirmed effect of age on its occurrence, studies were divided into three groups based on the age range of subjects namely $0-6$ years old (which also included studies on infants and pregnant mothers), 6-18 and above 18 years old.

Data extraction was performed blindly and the reviewers were not aware of the authors' names, institution, university or journal of the articles. In specific cases, the authors were contacted via email to obtain the raw data.

Studies collected in a systematic review are widely variable. Such diversity among articles is referred to as heterogeneity. Determining the type of heterogeneity is valuable. Differences among the study subjects (participants), type of intervention performed and the measurement scales used are known as clinical diversity or clinical heterogeneity. Diversity in the study design (methodology) and risk of bias of articles is referred to as methodological diversity or methodological heterogeneity. Diversity in the effects of interventions measured in different studies is referred to as statistical heterogeneity, which is the outcome of clinical or methodological diversity or both and is more important than other types of heterogeneities. The latter was used in our study and is simply referred to as heterogeneity. ${ }^{15}$

Considering the fact that method of reporting the data was variable in different studies and it was not always possible to contact the corresponding authors, we had to compare studies reporting the logarithm $\left(\log _{10}\right)$ of the number of bacteria in one group; those reporting the colony counts as frequency values were compared with each other in another group.

Analyses were carried out using the RevMan computer program version $5.3 .{ }^{16}$
After data extraction, heterogeneity tests were used for analysis of data. The final result was obtained by weighing the results of each study based on data dispersion and the assumption of one second colony count in the two groups was calculated using weighted confidence interval.

To assess the quality of RCTs, the retrieved articles were independently reviewed by two reviewers in terms of randomization and to prevent the effect of blinding on the results. The reviewers were not aware of the name of authors, institution, university or the journal.

\section{Results}

A total of 262,944 articles were found in Medline and 345,675 in Scopus. After applying the above-mentioned inclusion and exclusion criteria regarding the publication year, study design, English language and scope of the journal, 46 articles were found in PubMed and 356 in Scopus. The articles were entered into EndNote to eliminate duplicates. A total of 404 articles were separately and independently reviewed by the reviewers in terms of their methodology. Finally, 22 out of 46 articles found in PubMed and 30 out of 356 found in Scopus were included. A total of 52 articles were evaluated in terms of age group of participants, number of study groups, statistical population, sugars compared, time points of assessment, duration of follow-up and measurement scales.

With regard to the groups compared, 34 articles compared xylitol with at least one control group; 10 articles compared xylitol with sorbitol; four articles compared sorbitol with one control group; three articles compared xylitol, sorbitol and erythritol; two articles compared erythritol and a control group and five articles compared xylitol and erythritol. Among all, those comparing xylitol and a control group were selected and the remainders were excluded.

The above-mentioned 52 articles were also compared in terms of outcome; out of which, two had used DMFT, and three had used DMFS and 24 counted $S$. mutans colonies to assess the anti-cariogenic effects of sugars. As stated earlier, counting of $S$. mutans colonies was an inclusion criterion for our study.

The remaining 15 articles were divided into four groups based on the age group of their target population: four articles had been conducted on subjects aged 0-6 years, five articles had been conducted on 6-18 years old and two articles had been conducted on above 18 years old. Four articles had evaluated infants and pregnant mothers (Fig. 1).

Among five articles on 6-18 years old, only two by Holgerson et al. ${ }^{17}$ and Campus et al. ${ }^{18}$ had reported the mean and standard deviation of colony counts; the remaining articles had reported frequency values or were not suitable for assessment. The heterogeneity measured for the above-mentioned two articles is depicted in Forest Diagram. No heterogeneity was found in this respect $(\chi=0.05, \mathrm{~d} f=1, P=0.83$ ) (Fig. 2). The weight of results based on the dispersion of data for the Holgerson's study was $0.8 \%$; the weight of results for the study by Campus was $99.2 \%$. The results show the difference in $\log _{10}$ CFUs $/ \mathrm{ml}$ to be 0.08 ; which was not significant (based on the $P$ - and $Z$-values).

Among articles Campus et al. ${ }^{19}$ and Milgrom et al. ${ }^{20}$ on above 18 years old, the effect of xylitol was found to be significant ( $P=0.04$ and $Z=2.10$ ) (Fig. 3); however, it was not significant in the age group of $0-6$ years $^{21,22}(P=0.34)$ (Fig. 4). 


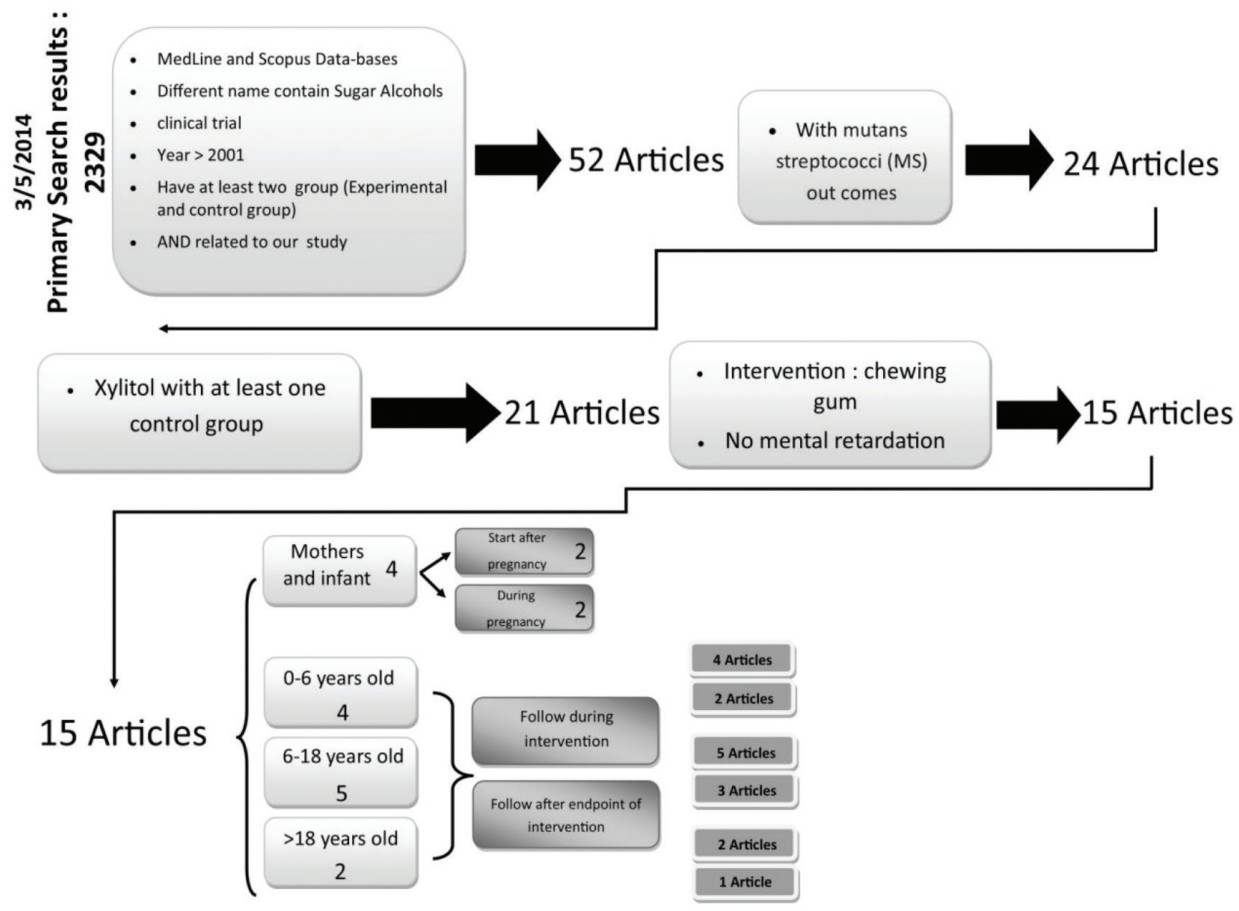

Fig. 1 Search diagram of articles.

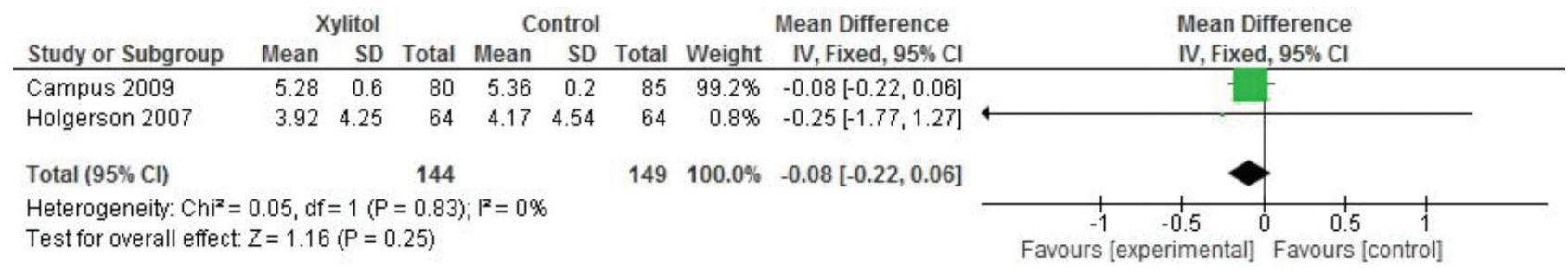

Fig. 2 Forest plot for comparing xylitol with control group among 6-18 years old.

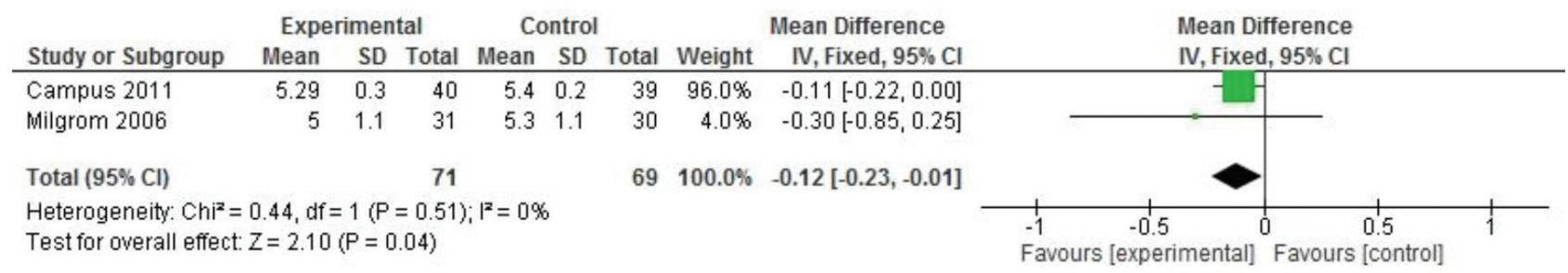

Fig. 3 Forest plot for comparing xylitol with control group among above 18 years old.

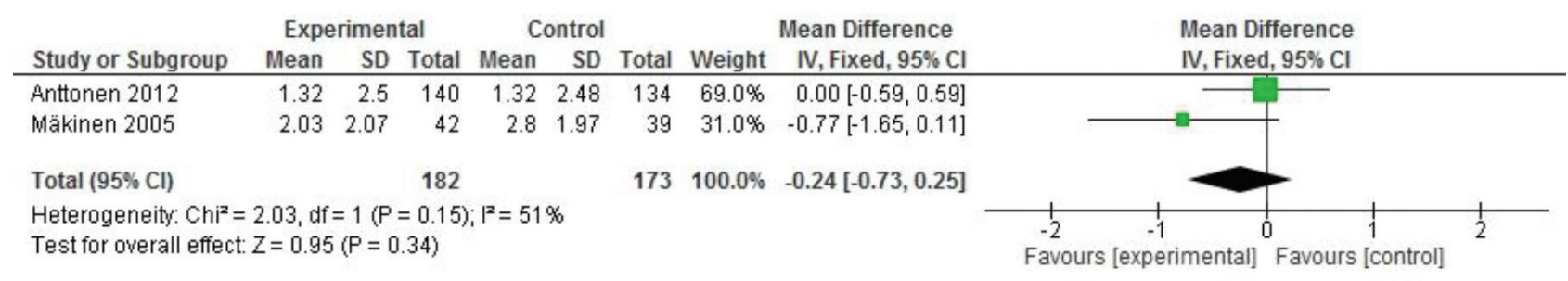

Fig. 4 Forest plot for comparing xylitol with control group among 0-6 years old. 
To compare all age groups and assess the effect of age on the results, the three groups were entered into the analysis irrespective of the age of subjects. The results showed complete homogeneity ( $\left.I^{2}=0 \%, P=0.01\right)$ (Fig. 5).

Since the $I^{2}$ value is calculated to convert heterogeneity to a quantitative value, this index in the analysis of the two groups was calculated to be $0 \%$; the heterogeneity was calculated to be $51 \%$ only in the age group of $0-6$ years; based on the definition of $I^{2}$ values, this group had moderate heterogeneity.

0-40\%: might not be important.

30-60\%: may represent moderate heterogeneity.

50-90\%: may represent substantial heterogeneity.

75-100\%: considerable heterogeneity.

Studies, which were subjected to statistical analyses are presented in Table 1.

\section{Discussion}

Based on the results, in articles on the age groups of 6-18 and 0-6 years old, consumption of xylitol and reduction in
S. mutans colony counts were not significantly correlated; but in the age group of above 18 years old, a significant association existed between the consumption of xylitol and reduction in $S$. mutans colony count $(P=0.04)$. Also, analysis of all articles irrespective of the age of subjects showed a significant correlation in this regard $(P=0.01)$.

However, it should be kept in mind that xylitol has recently found popularity for use in food products due to its anti-cariogenic activity; thus, number of studies, particularly RCTs on xylitol is small compared with those on other cariostatic agents such as fluoride. Also, use of different methodologies with regard to factors such as dosage of consumption by the participants, time and frequency of consumption, time of sampling, simultaneous use of other preventive measures such as fluoridated toothpastes and duration of follow-up made accurate comparison of articles difficult, if not impossible. Also, it should be noted that some previous studies ignored the anti-caries effect of chewing gum and thus, did not provide their control groups with gums to chew to simulate the saliva stimulation effect of xylitol gums in experimental groups.

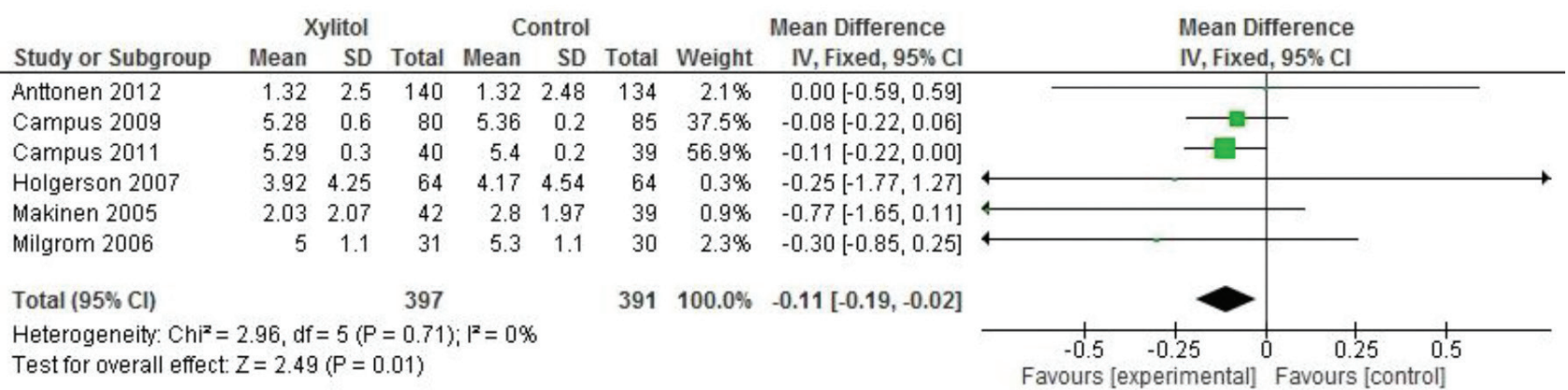

Fig. 5 Forest plot for comparing xylitol with control group among all ages.

\begin{tabular}{|c|c|c|c|c|}
\hline Author & Methods & Participants & Intervention & Outcome \\
\hline \multirow[t]{2}{*}{$\begin{array}{l}\text { Campus et al., }{ }^{18} \\
\text { Italy }\end{array}$} & & \multirow{2}{*}{$\begin{array}{l}204 \text { Subjects (acceptance rate } \\
88.3 \% \text { ). Inclusion criteria were: } \\
>1 \text { and }<4 \text { carious lesions, and a } \\
\text { salivary S. mutans concentration } \\
>10^{5} \text { CFUs/ml. }\end{array}$} & Xylitol versus control & $\begin{array}{l}\text { S. mutans } \\
\text { CFUs/ml in saliva }\end{array}$ \\
\hline & & & $\begin{array}{l}\text { Total daily intake of xylitol was } \\
11.6 \text { g. The chewing times were } \\
8.30 \text { a.m. and 1.00, } 3.00,6.00 \text { and } \\
9.00 \text { p.m. }\end{array}$ & Plaque $\mathrm{pH}$ \\
\hline \multirow[t]{4}{*}{$\begin{array}{l}\text { Holgerson et al., }{ }^{17} \\
\text { Sweden }\end{array}$} & \multirow{2}{*}{$\begin{array}{l}\text { Double-blind randomized } \\
\text { controlled trial with two } \\
\text { parallel arms. }\end{array}$} & \multirow{4}{*}{$\begin{array}{l}128 \text { Children (mean age }=12.7 \\
\text { years) consented to participate. } \\
\text { The children were stratified as } \\
\text { having caries experience (DMFS/ } \\
\text { DMFS } \geq 1 \text { ) or not. }\end{array}$} & $\begin{array}{l}\text { Xylitol versus control (sorbitol and } \\
\text { maltilol) }\end{array}$ & \multirow{4}{*}{$\begin{array}{l}\text { Visible plaque } \\
\text { index, salivary } \\
\text { mutans strep- } \\
\text { tococci counts } \\
\text { and salivary lactic } \\
\text { acid production. }\end{array}$} \\
\hline & & & $\begin{array}{l}\text { Two pellets, three times daily for } \\
4 \text { weeks }\end{array}$ & \\
\hline & Random allocation & & \multirow[t]{2}{*}{ Total dose $=6.18 \mathrm{~g} /$ day. } & \\
\hline & $\begin{array}{l}\text { Samples were collected at } \\
\text { baseline and immediately } \\
\text { after the test period. }\end{array}$ & & & \\
\hline \multirow{4}{*}{$\begin{array}{l}\text { Milgrom et al., }{ }^{20} \\
\text { USA }\end{array}$} & Randomized allocation & \multirow{4}{*}{$\begin{array}{l}132 \text { Participants had a mean age } \\
\text { of } 35 \text { years (range 18-73). }\end{array}$} & \multirow{3}{*}{$\begin{array}{l}\text { Controls (G1) (sorbitol/maltitol), or } \\
\text { combinations giving xylitol } 3.44 \mathrm{~g} / \\
\text { day (G2), } 6.88 \mathrm{~g} / \text { day (G3), or } 10.32 \\
\text { g/day (G4). }\end{array}$} & \multirow{4}{*}{$\begin{array}{l}\text { S. mutans in } \\
\text { saliva and } \\
\text { plaque. }\end{array}$} \\
\hline & Blinded & & & \\
\hline & \multirow[b]{2}{*}{$\begin{array}{l}\text { Controls (G1) (sorbitol/ } \\
\text { maltitol), or combinations } \\
\text { giving xylitol } 3.44 \mathrm{~g} / \mathrm{day}(\mathrm{G} 2) \text {, } \\
6.88 \mathrm{~g} / \text { day (G3), or } 10.32 \mathrm{~g} / \\
\text { day (G4). Groups chewed } \\
\text { three pellets/four times/day. }\end{array}$} & & & \\
\hline & & & $\begin{array}{l}\text { Groups chewed three pellets/four } \\
\text { times/day. Samples were taken at } \\
\text { baseline, } 5 \text { weeks, and } 6 \text { months. }\end{array}$ & \\
\hline
\end{tabular}




\begin{tabular}{|c|c|c|c|c|}
\hline Author & Methods & Participants & Intervention & Outcome \\
\hline \multirow{5}{*}{$\begin{array}{l}\text { Campus et al..19 } \\
\text { Italy }\end{array}$} & Double-blinded & \multirow{5}{*}{$\begin{array}{l}346 \text { Healthy subjects (age range } \\
18-30 \text { years) subjects who } \\
\text { presented more than one carious } \\
\text { lesion, but less than four, a sali- } \\
\text { vary S. mutans concentration } \\
6 \times 10^{5} \text { CFUs/ml and bleeding } \\
\text { on probing } 25 \% \text {. Subjects with a } \\
\text { history of systemic diseases were } \\
\text { excluded. }\end{array}$} & \multirow{4}{*}{$\begin{array}{l}\text { Magnolia chewing gums contained } \\
30 \% \text { xylitol, } 0.17 \% \text { MBE } \\
\text { (magnolol } 0.10 \% \text { and honokiol } \\
0.07 \% \text {, respectively), } 26 \% \text { sorbitol, } \\
11 \% \text { mannitol and } 1 \% \text { maltitol } \\
\text { syrup. Xylitol chewing gums } \\
\text { contained the same percentages } \\
\text { of the polyols mentioned, with no } \\
\text { other active ingredients. The control } \\
\text { chewing gum was sugar-free and } \\
\text { contained } 28 \% \text { isomalt, 31\% sorbitol, } \\
9 \% \text { mannitol and } 1 \% \text { maltitol syrup. }\end{array}$} & \multirow{2}{*}{$\begin{array}{l}\text { Salivary } \\
\text { S. mutans } \\
\text { (CFUs/ml) }\end{array}$} \\
\hline & Randomized allocation & & & \\
\hline & $\begin{array}{l}\text { Three groups: magnolia, } \\
\text { xylitol and control. }\end{array}$ & & & $\begin{array}{l}\text { Bleeding on } \\
\text { probing }\end{array}$ \\
\hline & \multirow[t]{2}{*}{$\begin{array}{l}\text { At baseline, after } 7 \text { days, after } \\
30 \text { days of gum use and } \\
7 \text { days after the end of } \\
\text { gum use. }\end{array}$} & & & \multirow[t]{2}{*}{ Plaque $\mathrm{pH}$. } \\
\hline & & & $\begin{array}{l}\text { The total daily intake of magnolol } \\
\text { and honokiol was } 11.9 \mathrm{mg} / \mathrm{day} \text {, and } \\
\text { for xylitol it was } 2.2 \mathrm{~g} / \text { day. }\end{array}$ & \\
\hline \multirow{5}{*}{$\begin{array}{l}\text { Anttonen et al. }{ }^{21} \\
\text { Finland }\end{array}$} & Double-blinded & \multirow{5}{*}{$\begin{array}{l}157 \text { Children (mean age } \\
5.0 \pm 1.4 \text { years) consumed xylitol } \\
\text { chewing gum and } 149 \text { children } \\
\text { (mean age } 4.9 \pm 1.5 \text { years) } \\
\text { sucrose chewing gum. No extra } \\
\text { preventive dental measures were } \\
\text { taken by the municipal health } \\
\text { center for any of the children } \\
\text { after the trial. }\end{array}$} & \multirow{5}{*}{$\begin{array}{l}\text { Xylitol versus control (sucrose) } \\
\text { Total amount of } 8.4 \mathrm{~g} \text { sucrose or } \\
\text { xylitol in chewing gum was given } \\
\text { daily in five doses for } 2 \text { months. }\end{array}$} & \multirow{5}{*}{$\begin{array}{l}\text { Salivary mutans } \\
\text { streptococci } \\
\text { (CFUs/ml). }\end{array}$} \\
\hline & Randomized & & & \\
\hline & allocation & & & \\
\hline & $\begin{array}{l}\text { Children used sucrose or } \\
\text { xylitol chewing gum regularly } \\
\text { for } 2 \text { months }\end{array}$ & & & \\
\hline & $\begin{array}{l}\text { Sample at baseline and after } \\
\text { intervention. }\end{array}$ & & & \\
\hline \multirow[t]{3}{*}{$\begin{array}{l}\text { Mäkinen et al.., } \\
\text { Finland }\end{array}$} & Double-blinded & $\begin{array}{l}123 \text { Children with a mean age of } \\
5.03(0.53)\end{array}$ & Xylitol versus D-glucitol & \multirow[t]{3}{*}{$\begin{array}{l}\text { Plaque S. mutans } \\
\text { and plaque } \\
\text { index. }\end{array}$} \\
\hline & Randomized allocation & \multirow[t]{2}{*}{$\begin{array}{l}\text { Average DMFS of children was } \\
11.6 \text { (12.7). }\end{array}$} & \multirow[t]{2}{*}{$\begin{array}{l}\text { Daily consumption of xylitol and } \\
\text { D-glucitol was } 4.5-5 \mathrm{~g} \text { per subject. }\end{array}$} & \\
\hline & $\begin{array}{l}\text { Interproximal dental plaque } \\
\text { was sampled at baseline and } \\
\text { after } 6 \text { months. }\end{array}$ & & & \\
\hline
\end{tabular}

We did not have access to all databases, and non-English manuscripts were not evaluated in our study either. Moreover, there were several studies, which met the required criteria to enter into the analysis; however, due to their specific method of reporting data, which was different from that of other articles (not reporting the mean and standard deviation values), they were not included in this study. Contacting the corresponding authors was not helpful either.

Despite all the above-mentioned limitations, we precisely conducted this study using the most recent guideline provided by the Cochrane website free of charge. ${ }^{15,16}$ For more accurate analysis of articles that met our inclusion criteria, only those with similar dosages and sampling time points were entered into the final analysis; which is strength of this systematic review.

A review study by Mickenautsch and Yengopal ${ }^{23}$ evaluated eight articles on the efficacy of xylitol and sorbitol for caries control and approved the efficacy of xylitol as an alternative anti-caries sugar However, in contrast to our study, they set no age limitation in their inclusion/exclusion criteria; also, their outcome was rate of caries and use of clinical caries indexes such as DMFS.

Some other review studies have also been performed in this regard in the recent years, with the same results as ours. For instance, Mickenautsch et al. ${ }^{10}$ confirmed the anticariogenic effect of immediate use of xylitol after eating by reviewing nine studies. Also, Deshpande and $\mathrm{Jadad}^{24}$ and Rethman et al. ${ }^{25}$ reviewed 19 and 15 articles, respectively. Antonio et al. ${ }^{26}$ reviewed three articles on the anti-caries effects of xylitol and confirmed its anti-caries efficacy for areas other than the interproximal surfaces. All the abovementioned studies used xylitol-containing products such as candies and lozenges in addition to chewing gums; these products may have stronger anti-caries effects by further stimulating the secretion of saliva and subsequent increase in the level of $\mathrm{pH}$. However, Bader et al., ${ }^{27}$ in a review study stated that the available evidence is not sufficient to confirm the anticaries effects of xylitol. Similarly, Lingström et al. ${ }^{9}$ compared nine articles and concluded the same result. Based on our findings and similar results reported in most previous studies, insignificant efficacy of xylitol in studies on $0-6$ and 6-18 years old may be due to several factors. Although $S$. mutans is an important cause of development of caries, our obtained result is exclusively related to this outcome while dental caries is a multifactorial disease. Moreover, subjects in these two age groups have less information and control over their personal oral hygiene compared with those above 18 years of age. Also, older subjects have better cooperation with the researchers. The results of each study alone confirm the efficacy of xylitol for decreasing $S$. mutans colony counts. However, the magnitude of this effect remains questionable. Further RCTs on larger sample sizes and with similar dosages, methods of measurements and equal outcomes are required. One major concern regarding the use of xylitol is its proper daily dosage. Fontana and González-Cabezas ${ }^{14}$ evaluated several systematic reviews and reported a suitable mean value of $6 \mathrm{~g} /$ day based on a range of $2.9-10.67 \mathrm{~g} / \mathrm{day}$, used in most studies. But, they also stated that there were two exceptions to this rule. 
First, twice daily use of fluoridated toothpaste with only $10 \%$ xylitol (equals approximately $0.02 \mathrm{~g} /$ day) caused a significant reduction in the rate of caries. ${ }^{28}$ The second exception was delay in formation of $S$. mutans colonies in infants whose mothers used $>5 \mathrm{~g}$ and in some cases $<2 \mathrm{~g} /$ day xylitol in their first years of life. ${ }^{29-32}$ This was also true for one of the articles, which was entered into our analysis. In the study by Milgrom et al. ${ }^{20}$ three different doses of xylitol namely 3.44, 6.88 and $10.32 \mathrm{~g}$ were used; the two groups of 6.88 and $10.32 \mathrm{~g}$ showed significant efficacy while $3.44 \mathrm{~g}$ xylitol had no significant effect on $S$. mutans colony count. Campus et al. ${ }^{19}$ assessed the efficacy of consumption of $2.2 \mathrm{~g}$ xylitol/day by the age group of above 18 years old and reported significant reduction in the number of $S$. mutans colonies and a subsequent reduction in the rate of caries. The mean dose of daily consumption of xylitol in $0-6,6-18$ and above 18 years old age groups was 8.34, 5.19 and 2.82, respectively. Another reason explaining the significant effect of xylitol reported in previous studies is its significant effect on those above 18 years old and insignificant effects on the other two age groups. The significant effect of xylitol irrespective of age may be due to the difference in its daily dosage. For instance, in the age group of 6-18 years old in the study by Campus et al., ${ }^{18} 11.6 \mathrm{~g}$ xylitol was used per day; whereas, in the study by Holgerson et al., ${ }^{17}$ almost half of this dosage $(6.18 \mathrm{~g})$ was used daily. Also, studies by Anttonen et al., ${ }^{21}$ and Mäkinen et al., ${ }^{22}$ reported the use of 8.4 and $4.55 \mathrm{~g}$ xylitol/day, which are widely different. This difference can probably result in different outcomes. Thus, an effective dose of xylitol for caries reduction is still a matter of debate and further studies are required to find the most effective dosage of xylitol to achieve the highest cariostatic effects.

\section{Conclusion}

Based on the results, the available literatures show xylitol as an alternative sweetener, which is capable of preventing dental caries by reducing the count of $S$. mutans in the saliva. The daily dosage of xylitol as an anti-caries agent is still controversial and calls for further investigations.

\section{Acknowledgments}

The authors declare no potential conflicts of interest with respect to authorship and/or publication of this article. This manuscript is based on a thesis (Thesis number: 44) submitted to Faculty of Dentistry, Tehran University of Medical Sciences, International Campus, Tehran, Iran, in partial fulfillment of the requirements for the D.D.S degree.

\section{Conflicts of Interest}

None.

\section{References}

1. Fejerskov O. Changing paradigms in concepts on dental caries: consequences for oral health care. Caries Res. 2004:38:182-191.

2. Marthaler TM. Changes in dental caries 1953-2003. Caries Res. 2004;38: 173-181.

3. Petersen PE, Bourgeois D, Ogawa H, Estupinan-Day S, Ndiaye C. The global burden of oral diseases and risks to oral health. Bull World Health Organ. 2005:83:661-669.

4. Gonçalves AF, Maia LC, Vianna R, Quintanilha LELP. Preventive strategies in oral health promotion. Cien Saude Colet. 2005;10:279-286.

5. Burt BA. The use of sorbitol- and xylitol-sweetened chewing gum in caries control. J Am Dent Assoc. 2006;137:190-196.

6. Isogangas P, Mäkinen KK, Tiekso J, Alanen P. Long-term effect of xylito chewing gum in the prevention of dental caries: a follow-up 5 years after termination of a prevention program. Caries Res. 1993:27:495-498.

7. Mäkinen KK, Bennett CA, Hujoel PP, Isokangas PJ, Isotupa KP. Pape HR, et al. Xylitol chewing gums and caries rates: a 40-month cohort study. J Dent Res. 1995;74:1904-1913.

8. Scheinin A, Pienihäkkinen K, Tiekso J, Bánóczy J, Szöke J, Esztári l, et al. Collaborative who xylitol field studies in hungary. VII. Two-year caries incidence in 976 institutionalized children. Acta odontol Scand. 1985;43:381-387.

9. Lingström P, Holm AK, Mejàre I, Twetman S, Söder B, Norlund A, et al. Dietary factors in the prevention of dental caries: a systematic review. Acta odontol Scand. 2003:61:331-340.

10. Mickenautsch S, Leal SC, Yengopal V, Bezerra AC, Cruvinel V. Sugar-free chewing gum and dental caries: a systematic review. J Appl Oral Sci. 2007; 15:83-88

11. Riley P, Moore D, Ahmed F, Sharif MO, Worthington HV. Xylitol-containing products for preventing dental caries in children and adults. Cochrane Database Syst Rev. 2015;3:CD010743.

12. Lin HK, Fang CE, Huang MS, Cheng HC, Huang TW, Chang HT, et al. Effect of maternal use of chewing gums containing xylitol on transmission of mutans streptococci in children: a meta-analysis of randomized controlled trials. Int J Paediatr Dent. 2016;26:35-44

13. Trahan L. Xylitol: a review of its action on mutans streptococci and dental plaque - its clinical significance. Int Dent J. 1995;45:77-92.

14. Fontana M, González-Cabezas C. Are we ready for definitive clinical guidelines on xylitol/polyol use? Adv Dent Res. 2012;24:123-128.

15. Higgins JPT, Green S (editors). Cochrane Handbook for Systematic Reviews of Interventions. Version 5.1.0. The Cochrane Collaboration, 2011. http:// handbook.cochrane.org/2011 [accessed March 2011].

16. The Nordic Cochrane Centre, The Cochrane Collaboration. Review manage (RevMan) [Computer program]. Version 5.3. The Nordic Cochrane Centre, The Cochrane Collaboration, Copenhagen, 2014 [accessed].

17. Holgerson PL, Sjöström I, Stecksén-Blicks C, Twetman S. Dental plaque formation and salivary mutans streptococci in schoolchildren after use of xylitol-containing chewing gum. Int J Paediatr Dent. 2007;17:79-85.

18. Campus G, Cagetti MG, Sacco G, Solinas G, Mastroberardino S, et al. Six months of daily high-dose xylitol in high-risk schoolchildren: a randomized clinical trial on plaque $\mathrm{pH}$ and salivary mutans streptococci. Caries Res. 2009:43:455-461

19. Campus G, Cagetti MG, Cocco F, Sale S, Sacco G, Strohmenger L, et al. Effect of a sugar-free chewing gum containing magnolia bark extract on different variables related to caries and gingivitis: a randomized controlled intervention trial. Caries Res. 2011:45:393-399.

20. Milgrom P, Ly KA, Roberts MC, Rothen M, Mueller G, Yamaguchi DK. Mutans streptococci dose response to xylitol chewing gum. J Dent Res. 2006;85:177-181.

21. Anttonen V, Halunen I, Päkkilä J, Larmas M, Tjäderhane L. A practice-based study on the effect of a short sucrose/xylitol exposure on survival of primary teeth caries free. Int J Paediatr Dent. 2012;22:356-362.

22. Mäkinen KK, Isotupa KP, Mäkinen PL, Söderling E, Song KB, Nam SH, et al. Six-month polyol chewing-gum programme in kindergarten-age children: a feasibility study focusing on mutans streptococci and dental plaque. Int Dent J. 2005;55:81-88

23. Mickenautsch S, Yengopal V. Effect of xylitol versus sorbitol: a quantitative systematic review of clinical trials. Int Dent J. 2012;62:175-188.

24. Deshpande A, Jadad AR. The impact of polyol-containing chewing gums on dental caries: a systematic review of original randomized controlled trials and observational studies. J Am Dent Assoc. 2008;139:1602-1614.

25. Rethman MP, Beltrán-Aguilar ED, Billings RJ, Hujoel PP, Katz BP, Milgrom P et al. Nonfluoride caries-preventive agents: executive summary of evidencebased clinical recommendations. J Am Dent Assoc. 2011;142:1065-1071.

26. Antonio AG, Pierro VS, Maia LC. Caries preventive effects of xylitol-based candies and lozenges: a systematic review. J Public Health Dent. 2011:71:117-124.

27. Bader JD, Shugars DA, Bonito AJ. Systematic reviews of selected dental caries diagnostic and management methods. J Dent Educ. 2001;65:960-968.

28. Sintes JL, Elias-Boneta A, Stewart B, Volpe AR, Lovett J. Anticaries efficacy of a sodium monofluorophosphate dentifrice containing xylitol in a dicalcium phosphate dihydrate base. A 30-month caries clinical study in Costa Rica. Am J Dent. 2002;15:215-219. 


\section{Review}

Effect of xylitol on salivary Streptococcus mutans: a systematic review and meta-analysis

29. Alamoudi NM, Hanno AG, Sabbagh HJ, Masoud MI, Almushayt AS, El Derwi DA. Impact of maternal xylitol consumption on mutans streptococci, plaque and caries levels in children. J Clin Pediatr Dent. 2012;37:163-166.

30. Isokangas P, Söderling E, Pienihäkkinen K, Alanen P. Occurrence of dental decay in children after maternal consumption of xylitol chewing gum, a follow-up from 0 to 5 years of age. J Dent Res. 2000;79:1885-1889.
31. Söderling $E$, Isokangas P, Pienihäkkinen $K$, Tenovuo J. Influence of maternal xylitol consumption on acquisition of mutans streptococci by infants. J Dent Res. 2000;79:882-887.

32. Thorild I, Lindau B, Twetman S. Caries in 4-year-old children after maternal chewing of gums containing combinations of xylitol, sorbitol, chlorhexidine and fluoride. Eur Arch Paediatr Dent. 2006;7:241-245.

This work is licensed under a Creative Commons Attribution-NonCommercial 3.0 Unported License which allows users to read, copy, distribute and make derivative works for non-commercial purposes from the material, as long as the author of the original work is cited properly. 